\title{
Overview of Pharmacokinetics and Liver Toxicities of Radix Polygoni Multiflori
}

\author{
Dan Li, Mengbi Yang and Zhong Zuo * \\ School of Pharmacy, The Chinese University of Hong Kong, Hong Kong 999077, China; \\ 1155133238@link.cuhk.edu.hk (D.L.); yangmb1022@gmail.com (M.Y.) \\ * Correspondence: joanzuo@cuhk.edu.hk
}

Received: 10 October 2020; Accepted: 19 November 2020; Published: 21 November 2020

\begin{abstract}
Radix Polygoni Multiflori (RPM), a traditional Chinese medicine, has been used as a tonic and an anti-aging remedy for centuries. However, its safe and effective application in clinical practice could be hindered by its liver injury potential and lack of investigations on its hepatotoxicity mechanism. Our current review aims to provide a comprehensive overview and a critical assessment of the absorption, distribution, metabolism, excretion of RPM, and their relationships with its induced liver injury. Based on the well-reported intrinsic liver toxicity of emodin, one of the major components in RPM, it is concluded that its plasma and liver concentrations could attribute to RPM induced liver injury via metabolic enzymes alteration, hepatocyte apoptosis, bile acids homeostasis disruption, and inflammatory damage. Co-administered $2,3,5,4^{\prime}$-tetrahydroxystilbene-2-O- $\beta$-D-glucopyranoside in RPM and other drugs/herbs could further aggravate the hepatotoxicity of emodin via enhancing its absorption and inhibiting its metabolism. To ensure the safe clinical use of RPM, a better understanding of the toxicokinetics and effect of its co-occurring components or other co-administered drugs/herbs on the pharmacokinetics of emodin is warranted.
\end{abstract}

Keywords: radix polygoni multiflori; herb induced liver injury; pharmacokinetics; mechanism; herb-drug/herb interaction

Key Contribution: The current review, for the first time, elucidates the relationships between the pharmacokinetics of the major bioavailable components in RPM and its hepatotoxicity. Based on our findings, emodin was considered to be the major component attributed to RPM liver toxicity. Additionally, a better understanding of the effect of its co-occurring components in RPM or other co-administered drugs/herbs on the pharmacokinetics of emodin is warranted for the safe clinical use of RPM.

\section{Introduction}

Radix Polygoni Multiflori (RPM) is the dry root of Polygonum multiflorum Thunb. (Fam. Polygonaceae). It could be used as raw material (raw RPM) or after steaming with black bean juice (processed RPM) in traditional Chinese medicine since the Tang dynasty with different indications [1]. According to Chinese Pharmacopeia, raw RPM at 3-6 g/person/day is mainly used for detoxification, eliminating carbuncle, preventing malaria, relaxing the bowel [1], while processed RPM at 3-12 g/person/day is used for nourishing the liver and kidney, supplementing the essence and blood, blackening hair, strengthening bones and muscles, eliminating dampness, and reducing lipids [1]. In addition to the clinical indications stated in Pharmacopeia, RPM and its major components, including 2,3,5, $4^{\prime}$-tetrahydroxystilbene-2-O- $\beta$-D-glucopyranoside (TSG), emodin, emodin-8-O- $\beta$-D-glucopyranoside (EMG), and polysaccharides have also demonstrated 
pharmacological activities for anti-aging [2,3], immunomodulating [4,5], hepatoprotective [6,7], anticancer [8], and anti-inflammatory [9] effects, etc., in various preclinical studies.

Despite the wide use of RPM as a medicine or health supplement, an increasing number of hepatic adverse effect reports of RPM or proprietary Chinese medicinal products containing it have been constantly received since the 1990s in China and other countries [10-16]. Since the occurrence of hepatotoxicity cases associated with RPM has raised serious concerns regarding its safety in clinical practice, drug regulatory agencies of Canada, Australia, the United Kingdom (UK), and China have conducted monitoring of the usage of RPM [17-20]. To explore the potential hepatotoxicity mechanisms of RPM, many preclinical studies on the pharmacokinetic characteristics and liver injury mechanisms associated with RPM and its major constituents, including TSG, emodin, and physcion, have been performed. Besides hepatotoxicity, it was found that emodin, the major component of RPM, also has carcinogenic activity and kidney toxicity [21]. Although the botany, phytochemistry, quality evaluation, traditional uses, pharmacological research, and toxicology of RPM have been well-reviewed [22-24], there is no comprehensive information about the pharmacokinetic characteristics of RPM and mechanisms of its induced liver injury. To ensure the safe and effective application of RPM in clinics, we proposed a comprehensive overview and a critical assessment of the published data concerning the absorption, distribution, metabolism, excretion, and hepatotoxicity mechanisms of RPM components. Moreover, the potential relationship between the pharmacokinetics of RPM and its induced liver injury as well as the role of herb-drug/herb interaction in RPM induced liver injury is also discussed in our current review.

To achieve the above goals, the following databases were searched to identify relevant literatures in both English and Chinese: PubMed (from 1981 to September 2020) and China National Knowledge Infrastructure (CNKI, from 1988 to September 2020). Both Latin and Chinese pinyin terms, including "Polygoni Multiflori", "Polygonum mutliflorum", and "Heshouwu" were used as keywords to search the herb-related articles, and keywords including "2,3,5,4'-tetrahydroxystilbene-2-O- $\beta$-D-glucopyranoside", "emodin", and "physcion" were used for the search of compound-related articles. Exclusion criteria were as follows: (1) full text not available, (2) review articles on animal studies, (3) irrelevant in vitro studies using an herbal extract. In total, 54 articles, including 10 clinical studies, 35 animal studies, and 13 in vitro studies that contained information involving the pharmacokinetics and/or hepatic injury mechanisms of RPM or the major components, including TSG, emodin, and physcion, were identified in the current review, and the findings are highlighted as follows.

\section{Chemical Constituents in RPM}

Major chemical constituents in RPM include stilbenes, anthraquinones, flavonoids, and phenolic acids, etc. $[25,26]$, with stilbenes and anthraquinones as the two major phytochemical groups for these components. As shown in Figure 1, among the stilbenes, including TSG, resveratrol, and oxyresveratrol, TSG is the most abundant. Among the major anthraquinones, including emodin, physcion, aloe-emodin, rhein, chrysophanol, EMG, emodin-8-O-(6'-O-malonyl)-glucopyranoside, physcion-8-O- $\beta$-D-glucopyranoside, and physcion-8-O-(6'-O-malonyl)-glucopyranoside. etc., emodin and EMG are the two most abundant $[25,27,28]$. Processing of RPM could decrease the contents of EMG and physcion-8-O- $\beta$-D-glucopyranoside and increase that of their corresponding aglycones, emodin, and physcion [28]. Chinese Pharmacopeia suggests that contents of TSG should not be less than $1.0 \%$ and $0.7 \%$ in the raw material and processed herb of RPM, respectively, and the combined contents of emodin and physcion should be greater than $0.1 \%$ in both raw and processed RPM [1]. The Hong Kong Standard of Material of Medica requires that the content of TSG should not be less than $2.2 \%$ in raw RPM [29]. 


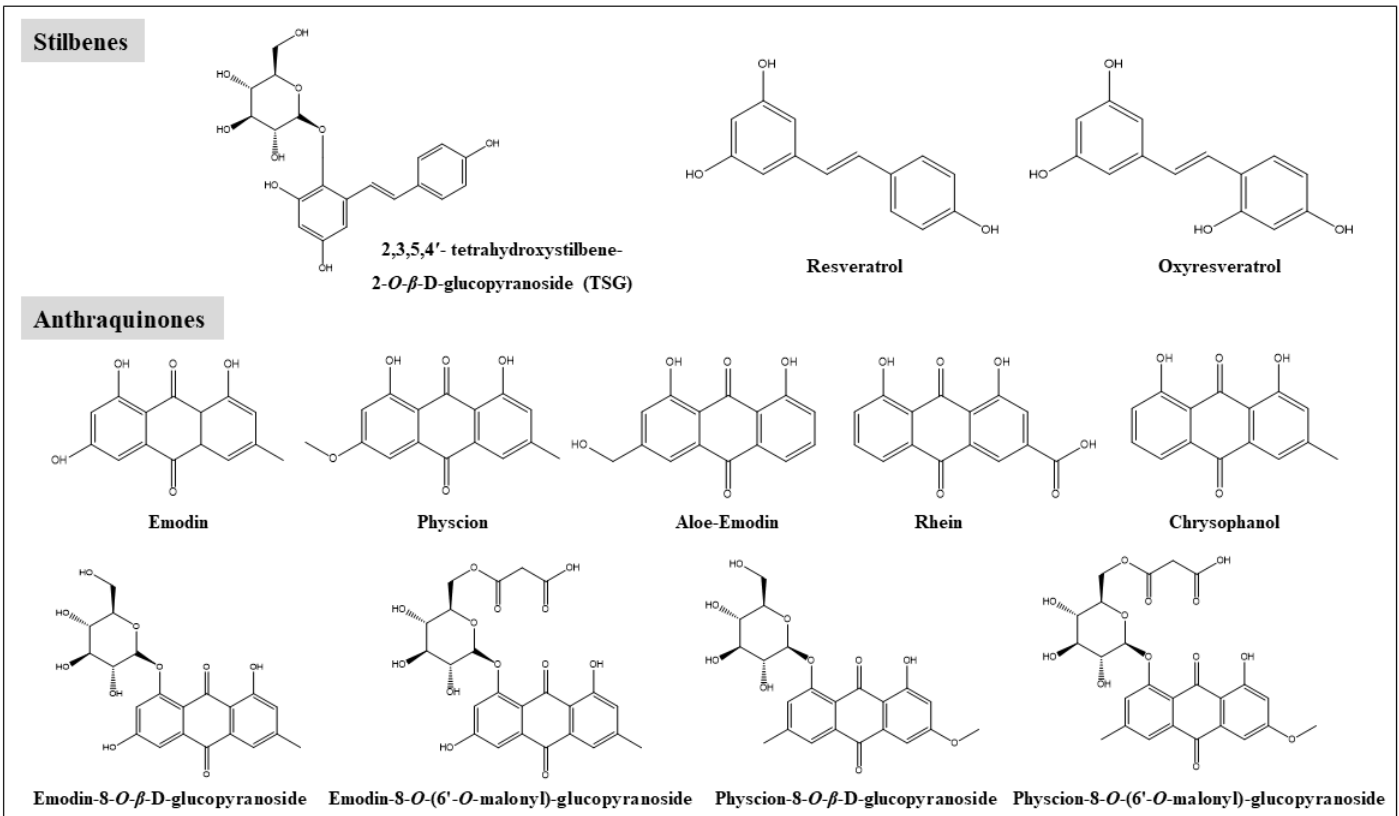

Figure 1. Chemical structures of the major components in Radix Polygoni Multiflori (RPM) extract.

\section{Pharmacokinetics of RPM}

\subsection{Pharmacokinetic Studies of RPM Extract}

So far, pharmacokinetics properties of the major components in RPM extract have primarily been investigated in rats. As shown in Table 1, TSG, emodin, EMG, aloe-emodin, physcion, oxyresveratrol, and rhein could be detected after oral administrations of RPM extracts (equivalent to $40 \mathrm{~g}$ raw RPM/kg) to rats. With the doses decreasing from $40 \mathrm{~g} / \mathrm{kg}$ to $10 \mathrm{~g} / \mathrm{kg}$ and $20 \mathrm{~g} / \mathrm{kg}$, oxyresveratrol and rhein became undetectable in plasma [25]. The pharmacokinetic parameters indicated that the absorption and elimination of these major components were generally fast with time to maximum plasma concentration $\left(\mathrm{T}_{\max }\right)$ less than $2 \mathrm{~h}$ for TSG, emodin, and physcion, and half-lives of these three compounds ranged from 0.18 to $8.37 \mathrm{~h}$ after a single dose of RPM extracts orally administrated to SD rats [25,27,30-32]. Since the area under the concentration-time curve (AUC) and peak concentration $\left(\mathrm{C}_{\max }\right)$ of TSG and emodin increased linearly along with the dose of RPM extract increasing from $10 \mathrm{~g} / \mathrm{kg}$ (TSG: $327.9 \mathrm{mg} / \mathrm{kg}$, emodin: $5.6 \mathrm{mg} / \mathrm{kg}$ ) to $40 \mathrm{~g} / \mathrm{kg}$ (TSG: $1312.0 \mathrm{mg} / \mathrm{kg}$, emodin: $22.3 \mathrm{mg} / \mathrm{kg}$ ), linear pharmacokinetics of TSG, and after single oral administration of RPM extracts in rats, were suggested [25].

The pharmacokinetics of TSG, emodin, and EMG after multiple dosing of RPM extracts to SD rats [33] found that the AUC and $C_{\max }$ values of TSG and emodin could significantly increase after 11 days of treatment of RPM extracts, which could be attributed to the change in metabolic enzymes after repeated RPM extracts administrations [34]. As for EMG, it was only detectable at a few time points after prolonged treatment of RPM, possibly due to its low content in RPM and low oral bioavailability in vivo. 
Table 1. Plasma pharmacokinetic parameters of the major components in Radix Polygoni Multiflori (RPM) after oral administrations of its extract to SD rats.

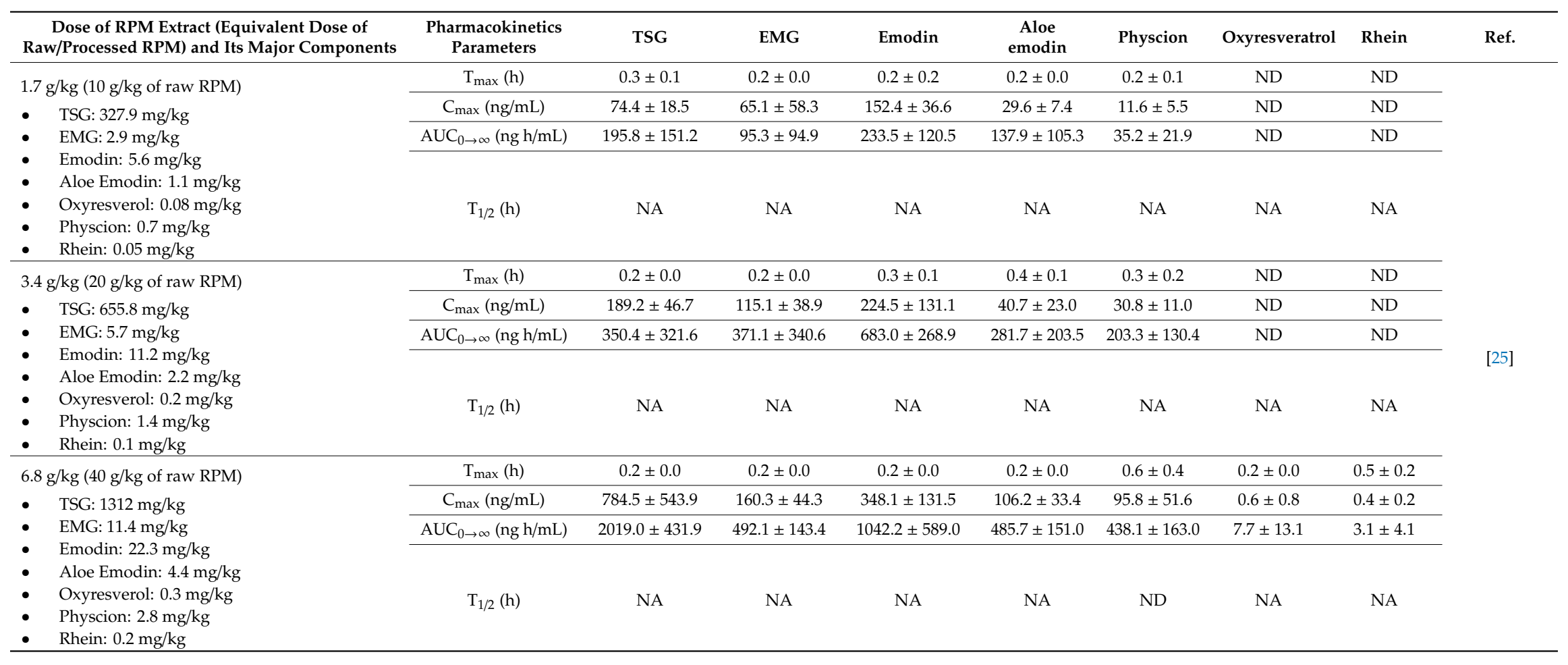


Table 1. Cont

\begin{tabular}{|c|c|c|c|c|c|c|c|c|c|}
\hline $\begin{array}{l}\text { Dose of RPM Extract (Equivalent Dose of } \\
\text { Raw/Processed RPM) and Its Major Components }\end{array}$ & $\begin{array}{l}\text { Pharmacokinetics } \\
\text { Parameters }\end{array}$ & TSG & EMG & Emodin & $\begin{array}{c}\text { Aloe } \\
\text { emodin }\end{array}$ & Physcion & Oxyresveratrol & Rhein & Ref. \\
\hline \multirow{4}{*}{$\begin{array}{ll}\text { NA } & (36 \mathrm{~g} / \mathrm{kg} \text { of raw RPM) } \\
\text { - } & \text { TSG: } 1170 \mathrm{mg} / \mathrm{kg} \\
\text { - } & \text { EMG: } 31.4 \mathrm{mg} / \mathrm{kg} \\
\text { - } & \text { Emodin: } 14.8 \mathrm{mg} / \mathrm{kg} \\
\text { - } & \text { Oloe Emodin: } 13.7 \mathrm{mg} / \mathrm{kg} \\
\text { - } & \text { Physcion: } 15.5 \mathrm{mg} / \mathrm{kg} \\
\text { - } & \text { Rhein: } 8.8 \mathrm{mg} / \mathrm{kg} \\
\end{array}$} & $\mathrm{T}_{\max }(\mathrm{h})$ & $0.3 \pm 0.1$ & $0.3 \pm 0.1$ & $0.2 \pm 0.1$ & $0.2 \pm 0.1$ & ND & NA & $0.5 \pm 0.1$ & \multirow[b]{4}{*}[30]{} \\
\hline & $\mathrm{C}_{\max }(\mathrm{ng} / \mathrm{mL})$ & $1743.0 \pm 401.0$ & $101.0 \pm 47.4$ & $175.0 \pm 33.8$ & $11.3 \pm 3.1$ & ND & NA & $1.1 \pm 0.2$ & \\
\hline & $\mathrm{AUC}_{0 \rightarrow \infty}(\mathrm{ng} \mathrm{h} / \mathrm{mL})$ & $1871.0 \pm 581.0$ & $83.7 \pm 32.3$ & $801.0 \pm 233.0$ & $8.5 \pm 3.4$ & ND & NA & $2.3 \pm 0.5$ & \\
\hline & $\mathrm{T}_{1 / 2}(\mathrm{~h})$ & $6.0 \pm 2.62$ & $3.9 \pm 2.5$ & $8.4 \pm 4.2$ & $3.4 \pm 1.4$ & ND & NA & $1.2 \pm 0.4$ & \\
\hline \multirow{3}{*}{$\begin{array}{l}3.3 \mathrm{~g} / \mathrm{kg}(19.19 \mathrm{~g} / \mathrm{kg} \text { of raw } \mathrm{RPM}) \\
\text { - } \quad \text { TSG: } 78.8 \mathrm{mg} / \mathrm{kg} \\
\text { - } \quad \text { Emodin: } 5.6 \mathrm{mg} / \mathrm{kg}\end{array}$} & $\mathrm{C}_{\max }(\mathrm{ng} / \mathrm{mL})$ & $884.0 \pm 146.0$ & NA & $89.9 \pm 13.6$ & \multirow{14}{*}{$\mathrm{NA}$} & \multirow{14}{*}{ NA } & \multirow{14}{*}{ NA } & \multirow{14}{*}{ NA } & \multirow{7}{*}{27} \\
\hline & $\mathrm{AUC}_{0 \rightarrow \infty}(\mathrm{ng} \mathrm{h} / \mathrm{mL})$ & $3292.0 \pm 707.0$ & NA & $1842.0 \pm 425.0$ & & & & & \\
\hline & $\mathrm{T}_{1 / 2}(\mathrm{~h})$ & $1.1 \pm 0.5$ & NA & $2.8 \pm 1.6$ & & & & & \\
\hline \multirow{4}{*}{$\begin{array}{l}1.7 \mathrm{~g} / \mathrm{kg}(18.00 \mathrm{~g} / \mathrm{kg} \text { of processed RPM) } \\
\text { - } \quad \text { TSG: } 48.8 \mathrm{mg} / \mathrm{kg} \\
\text { - } \quad \text { Emodin: } 12.6 \mathrm{mg} / \mathrm{kg}\end{array}$} & $\mathrm{T}_{\max }(\mathrm{h})$ & $0.4 \pm 0.1$ & NA & $0.2 \pm 0.0$ & & & & & \\
\hline & $\mathrm{C}_{\max }(\mathrm{ng} / \mathrm{mL})$ & $491.6 \pm 179.7$ & NA & $61.3 \pm 9.2$ & & & & & \\
\hline & $\mathrm{AUC}_{0 \rightarrow \infty}(\mathrm{ng} \mathrm{h} / \mathrm{mL})$ & $1137.0 \pm 401.6$ & NA & $879.9 \pm 195.0$ & & & & & \\
\hline & $\mathrm{T}_{1 / 2}(\mathrm{~h})$ & $0.3 \pm 0.0$ & NA & $1.7 \pm 0.6$ & & & & & \\
\hline \multirow{3}{*}{$\begin{array}{ll}\text { NA } & (6 \mathrm{~g} / \mathrm{kg} \text { of raw RPM) } \\
\text { - } & \text { TSG: } 212.2 \mathrm{mg} / \mathrm{kg} \\
\text { - } & \text { Emodin: } 4.9 \mathrm{mg} / \mathrm{kg} \\
\text { - } & \text { EMG: } 22.0 \mathrm{mg} / \mathrm{kg}\end{array}$} & $\mathrm{T}_{\max }(\mathrm{h})$ & $0.2 \pm 0.1$ & $0.3 \pm 0.1$ & $1.6 \pm 3.1$ & & & & & \multirow{3}{*}[31]{} \\
\hline & $\mathrm{AUC}_{0 \rightarrow \infty}(\mathrm{ng} \mathrm{h} / \mathrm{mL})$ & $90.2 \pm 35.8$ & $14.3 \pm 15.9$ & $506.3 \pm 61.6$ & & & & & \\
\hline & $\mathrm{T}_{1 / 2}(\mathrm{~h})$ & $2.2 \pm 1.6$ & $0.2 \pm 0.1$ & $5.0 \pm 1.7$ & & & & & \\
\hline \multirow{4}{*}{$\begin{array}{l}\text { NA }(10 \mathrm{~g} / \mathrm{kg} \text { of raw RPM) } \\
\text { - } \quad \text { No content report for TSG, emodin and EMG }\end{array}$} & $\mathrm{T}_{\max }(\mathrm{h})$ & $0.7 \pm 0.1$ & $1.0 \pm 0.6$ & $0.5 \pm 0.3$ & & & & & \multirow{4}{*}{ [32] } \\
\hline & $\mathrm{C}_{\max }(\mathrm{ng} / \mathrm{mL})$ & $240.2 \pm 114.0$ & $204.4 \pm 85.9$ & $76.7 \pm 13.2$ & & & & & \\
\hline & $\mathrm{AUC}_{0 \rightarrow \infty}(\mathrm{ng} \mathrm{h} / \mathrm{mL})$ & $373.6 \pm 142.7$ & $489.7 \pm 129.7$ & $395.2 \pm 208.3$ & & & & & \\
\hline & $\mathrm{T}_{1 / 2}(\mathrm{~h})$ & $1.6 \pm 0.6$ & $1.7 \pm 0.5$ & $6.5 \pm 1.4$ & & & & & \\
\hline
\end{tabular}

ND: not detectable; NA: not available. 


\subsection{Pharmacokinetic Properties of TSG, Emodin, and Physcion}

Besides RPM extract, the pharmacokinetics of pure compounds of TSG, emodin, and physcion in beagle dogs and SD rats have also been studied and summarized in Table 2. Among these three compounds, only TSG and emodin have been investigated for their oral bioavailabilities. The absolute oral bioavailabilities of TSG were reported to be $24.2 \%$ and $36.5 \%$ for $50 \mathrm{mg} / \mathrm{kg}$ and $100 \mathrm{mg} / \mathrm{kg}$ in SD rats, respectively [35]. Oral administered $8 \mathrm{mg} / \mathrm{kg}$ of emodin resulted in $6 \% \sim 9 \%$ bioavailability in SD rats. In addition, gender-specific pharmacokinetics of emodin was noticed with much higher $C_{\max } / A U C$, and a shorter half-life observed in male rats [36]. The $T_{\max }$ values among these major RPM components indicated their fast absorption, and comparison of the half-lives of these three compounds suggested the order of elimination rate as TSG > emodin > physcion [34-40]. The major characteristics of the absorption, distribution, metabolism, and elimination (ADME) for these compounds are highlighted below:

\subsubsection{Absorption}

The intestinal absorption processes of TSG observed in the Caco-2 monolayer model, and the in situ intestinal perfusion model revealed its moderate intestinal permeability with an apparent permeability coefficient $\left(\mathrm{P}_{\mathrm{app}}\right.$ ) of TSG in the range of 1 to $10 \times 10^{-6} \mathrm{~cm} / \mathrm{s}$ [41]. Due to the significantly increased effective intestinal permeability $\left(\mathrm{P}_{\text {eff }}\right)$ and absorption rate constant $\left(\mathrm{K}_{\mathrm{a}}\right)$ of TSG in the presence of verapamil hydrochloride, quinidine, and probenecid on the in situ intestinal perfusion model, transporters, including P-glycoprotein, and multidrug resistance-associated protein 2 (MRP2) were considered to be involved in the intestinal absorption of TSG [41]. After oral ingestion of TSG, the absorption rate of TSG was rather efficient with a $\mathrm{T}_{\max }$ of $60 \mathrm{~min}$ and $15 \mathrm{~min}$ in beagle dogs [37] and rats [35], respectively.

The absorption behavior of emodin was explored in both the Caco-2 monolayer model ( $\mathrm{P}_{\text {app }} \mathrm{A}$ to B: $\left.2 \times 10^{-6} \mathrm{~cm} / \mathrm{s}\right)$ and the rat in situ intestinal model ( $\left.\mathrm{P}_{\text {eff }}: 1.2 \times 10^{-3} \mathrm{~cm} / \mathrm{s}\right)$ [42-44], and both suggested its moderate intestinal absorption. Besides, transporters, including $\mathrm{Na}^{+} /$glucose cotransporter (SGLT1), MRP2, and P-glycoprotein, were also involved in the efflux transport of emodin, leading to its poor oral bioavailability. It was found that phloridzin (SGLT1 inhibitor) reduced the absorption of emodin [45] and verapamil (P-glycoprotein inhibitor), and cyclosporine (MRP inhibitor) could increase the uptake of emodin in Caco-2 cells in a dose-dependent manner [43,45]. However, the MRP2 inhibitor (indomethacin), rather than verapamil hydrochloride, could significantly increase the $\mathrm{K}_{\mathrm{a}}$ and $\mathrm{P}_{\text {eff }}$ of emodin in the rat in situ intestinal perfusion model [43], suggesting that MRP2 has more influence on the efflux transport of emodin than P-glycoprotein. The absorption rate of emodin was fast in both female and male rats with $T_{\max }$ less than 1 hour after ingesting 8 or $10 \mathrm{mg} / \mathrm{kg}$ of its pure compound [36,38].

Similar to TSG and emodin, physcion has a moderate intestinal permeability with $\mathrm{P}_{\text {eff }}$ values of $(3.32 \pm 1.50) \times 10^{-3},(2.30 \pm 1.57) \times 10^{-3},(2.40 \pm 0.58) \times 10^{-3},(7.45 \pm 3.30) \times 10^{-3} \mathrm{~cm} / \mathrm{min}$ in the duodenum, jejunum, ileum, and colon, respectively [46]. So far, there is no report on the transporter involved in the intestinal absorption of physcion yet. After oral administration of 26.4, 52.8, and $105.6 \mathrm{mg} / \mathrm{kg}$ physcion to rats, the absorption rate of physcion was fast with $\mathrm{T}_{\max }$ of less than $1 \mathrm{~h}$ [40]. 
Table 2. Preclinical plasma pharmacokinetic parameters of major RPM components after oral administrations of their pure compounds.

\begin{tabular}{|c|c|c|c|c|c|c|c|c|c|}
\hline Compounds & Species & $\begin{array}{l}\text { Dose, Route of } \\
\text { Administrations }\end{array}$ & $\begin{array}{c}C_{\max } \\
(\mu \mathrm{g} / \mathrm{mL})\end{array}$ & $\begin{array}{l}T_{\max } \\
\text { (h) }\end{array}$ & $\begin{array}{c}\mathrm{AUC}_{0 \rightarrow \mathrm{t}} \\
(\mu \mathrm{g} \mathrm{h} / \mathrm{mL})\end{array}$ & $\begin{array}{l}\mathrm{AUC}_{0 \rightarrow \infty} \\
(\mu \mathrm{g} \mathrm{h} / \mathrm{mL})\end{array}$ & $\begin{array}{l}\mathrm{T}_{1 / 2 \alpha} \\
\text { (h) }\end{array}$ & $\begin{array}{l}T_{1 / 2 \beta} \\
\text { (h) }\end{array}$ & Ref. \\
\hline \multirow{7}{*}{ TSG } & \multirow{3}{*}{ Beagle dogs } & $0.52 \mathrm{~g} / \mathrm{kg}$, p.o. & $0.83 \pm 0.04$ & $1.00 \pm 0.00$ & $1.53 \pm 0.07$ & $2.04 \pm 0.02$ & $0.20 \pm 0.02$ & $0.56 \pm 0.05$ & \multirow{3}{*}{ [37] } \\
\hline & & 0.78 g/kg, p.o. & $1.16 \pm 0.06$ & $1.00 \pm 0.00$ & $2.30 \pm 0.06$ & $3.00 \pm 0.19$ & $0.10 \pm 0.02$ & $0.60 \pm 0.03$ & \\
\hline & & 1.04 g/kg, p.o. & $2.17 \pm 0.23$ & $1.00 \pm 0.00$ & $3.60 \pm 0.02$ & $4.59 \pm 0.35$ & $0.14 \pm 0.02$ & $0.64 \pm 0.15$ & \\
\hline & \multirow{4}{*}{ SD rats } & 10 mg/kg, i.v. & $22.80 \pm 2.60$ & - & $5.10 \pm 0.33$ & $5.84 \pm 0.19$ & NA & NA & \multirow{4}{*}{ [35] } \\
\hline & & 20 mg/kg, i.v. & $64.20 \pm 3.60$ & - & $11.01 \pm 0.58$ & $12.23 \pm 0.98$ & NA & NA & \\
\hline & & 50 mg/kg, p.o. & $5.70 \pm 1.60$ & $0.25 \pm 0.02$ & $5.99 \pm 0.59$ & $7.09 \pm 1.87$ & NA & NA & \\
\hline & & 100 mg/kg, p.o. & $21.90 \pm 2.50$ & $0.24 \pm 0.02$ & $20.70 \pm 0.64$ & $21.29 \pm 0.63$ & NA & NA & \\
\hline \multirow{5}{*}{ Emodin } & \multirow{5}{*}{ SD rats } & $4 \mathrm{mg} / \mathrm{kg}$, i.v. & $5.83 \pm 2.34$ & - & $7.18 \pm 1.84$ & NA & NA & $1.38 \pm 0.59$ & \multirow{2}{*}{ [36] } \\
\hline & & 8 mg/kg, p.o. & $0.21 \pm 0.09$ & $0.30 \pm 0.11$ & $1.33 \pm 0.53$ & NA & NA & $6.42 \pm 1.72$ & \\
\hline & & 10 mg/kg, p.o. & $0.08 \pm 0.02$ & $0.75 \pm 0.00$ & $0.39 \pm 0.04$ & $0.42 \pm 0.05$ & NA & $2.98 \pm 0.71$ & [38] \\
\hline & & 20 mg/kg, p.o. & $6.04 \pm 1.14$ & NA & $13.18 \pm 2.99$ & $13.28 \pm 3.00$ & NA & $1.22 \pm 0.29$ & [39] \\
\hline & & 82.4 mg/kg, p.o. & $0.10 \pm 0.01$ & NA & $1.26 \pm 0.08$ & $1.30 \pm 0.02$ & $4.56 \pm 0.76$ & NA & [34] \\
\hline \multirow{3}{*}{ Physcion } & \multirow{3}{*}{ SD rats } & 26.4 mg/kg, p.o. & $0.29 \pm 0.12$ & $1.00 \pm 0.76$ & $45.84 \pm 36.00$ & NA & NA & $13.25 \pm 5.60$ & \multirow{3}{*}{ [40] } \\
\hline & & $52.8 \mathrm{mg} / \mathrm{kg}$, p.o & $0.41 \pm 0.15$ & $1.00 \pm 0.42$ & $47.52 \pm 33.60$ & NA & NA & $14.23 \pm 11.00$ & \\
\hline & & $105.6 \mathrm{mg} / \mathrm{kg}$, p.o & $0.49 \pm 0.17$ & $0.75 \pm 0.56$ & $78.70 \pm 31.20$ & NA & NA & $10.97 \pm 6.60$ & \\
\hline
\end{tabular}




\subsubsection{Distribution}

Among the major components in RPM, TSG demonstrated the quickest tissue distributions after its administrations in animals. It was detectable in tissues including heart, liver, spleen, lung, kidney, brain, small intestine, and stomach at $10 \mathrm{~min}$ after its oral administrations. Heart and kidney are the preferable tissues that TSG distributed to, followed by liver, lung, and stomach after $30 \mathrm{~min}$ post oral administration of $100 \mathrm{mg} / \mathrm{kg}$ TSG. Ten minutes after intravenous administration of TSG to rats, the liver was the major organ that TSG was preferably distributed to, followed by heart, lung, spleen, kidney, stomach, small intestine, brain, and testicles [35]. In summary, TSG showed an extensive and homogenous distribution into multiple tissues after both oral and intravenous administrations.

After oral administration of emodin, it was mainly distributed in the liver and kidney. Three hours after oral administration of $10 \mathrm{mg} / \mathrm{kg}$ emodin nanoformulation to rats, it could reach the peak concentrations in the major organs and distribute them in the order of liver, lung, kidney, heart, spleen, and brain [38]. In addition to these major organs, a sufficient amount of emodin was also found in mesenterium and adipose tissues after oral administrations of $10 \mathrm{mg}\left[{ }^{14} \mathrm{C}\right]$ emodin in rats [47]. Besides, a similar distribution in the liver and kidney in male rats, physcion was identified with gender-specific distribution due to no detectable amount in the tissues of female SD rats under the same experimental conditions [48].

\subsubsection{Metabolism}

Recent preclinical studies have revealed that phase II metabolism is the major metabolic pathway of TSG. After incubating TSG with rat liver microsome for $60 \mathrm{~min}$, only TSG glucuronide was determined [49]. After oral administration of TSG in rats, its glucuronidation metabolites were also identified as the major metabolites [35].

Unlike TSG, emodin undergoes both phase I and phase II metabolism, with phase II metabolism to be the dominant one, as summarized in Figure 2. In rat liver microsome system, the oxidative metabolism of emodin was at least five times slower than its glucuronidation [50], and the total AUC of emodin glucuronide and emodin sulfate was extremely close to that of emodin glucuronide after oral administration of $20 \mathrm{mg} / \mathrm{kg}$ or $40 \mathrm{mg} / \mathrm{kg}$ emodin to rats [51]. Since the intrinsic clearance $\left(\mathrm{CL}_{\text {int }}\right)$ of emodin in male rat jejunum $(74.5 \mathrm{~mL} /(\mathrm{h} \cdot \mathrm{mg}))$ is very close to that of the liver $(117.6 \mathrm{~mL} /(\mathrm{h} \cdot \mathrm{mg}))$ [50], much of the absorbed emodin was expected to be metabolized first in the intestine. After oral administration of emodin, it was absorbed across the intestine wall and converted into emodin-3-O- $\beta$-glucuronide $\left(\mathrm{CL}_{\text {int }}\right.$ in rat jejunum microsome: $\left.74.5 \mathrm{~mL} /(\mathrm{h} \cdot \mathrm{mg})\right)$ or other phase II metabolites, such as emodin sulfates and other emodin glucuronides [50]. About $22.55 \%$ of the administered emodin appeared at the vascular side, including $12.01 \%$ free emodin, $8.69 \%$ emodin glucuronide, and $1.84 \%$ emodin sulfate [52]. In rat liver, emodin could be either oxidized into emodic acid ( 6\%), 2-hydroxyemodin, 4-hydroxyemodin, $\omega$-hydroxyemodin, 3-carbomethoxy-6-methoxy-1,8-dihydroxyanthraquinone, and physcion [47,53], mainly by cytochrome P450 (CYP) 1A2 [54] or undergo phase II metabolism to form emodin glucuronides and emodin sulfates with emodin-3-O- $\beta$-glucuronide as the major metabolite [50,51]. The extensive metabolism via glucuronidation in rats may be one of the major reasons for the poor oral bioavailability of emodin in rats, which was reported to be $9.28 \%$ and $6.54 \%$ for male and female rats, respectively [36]. 


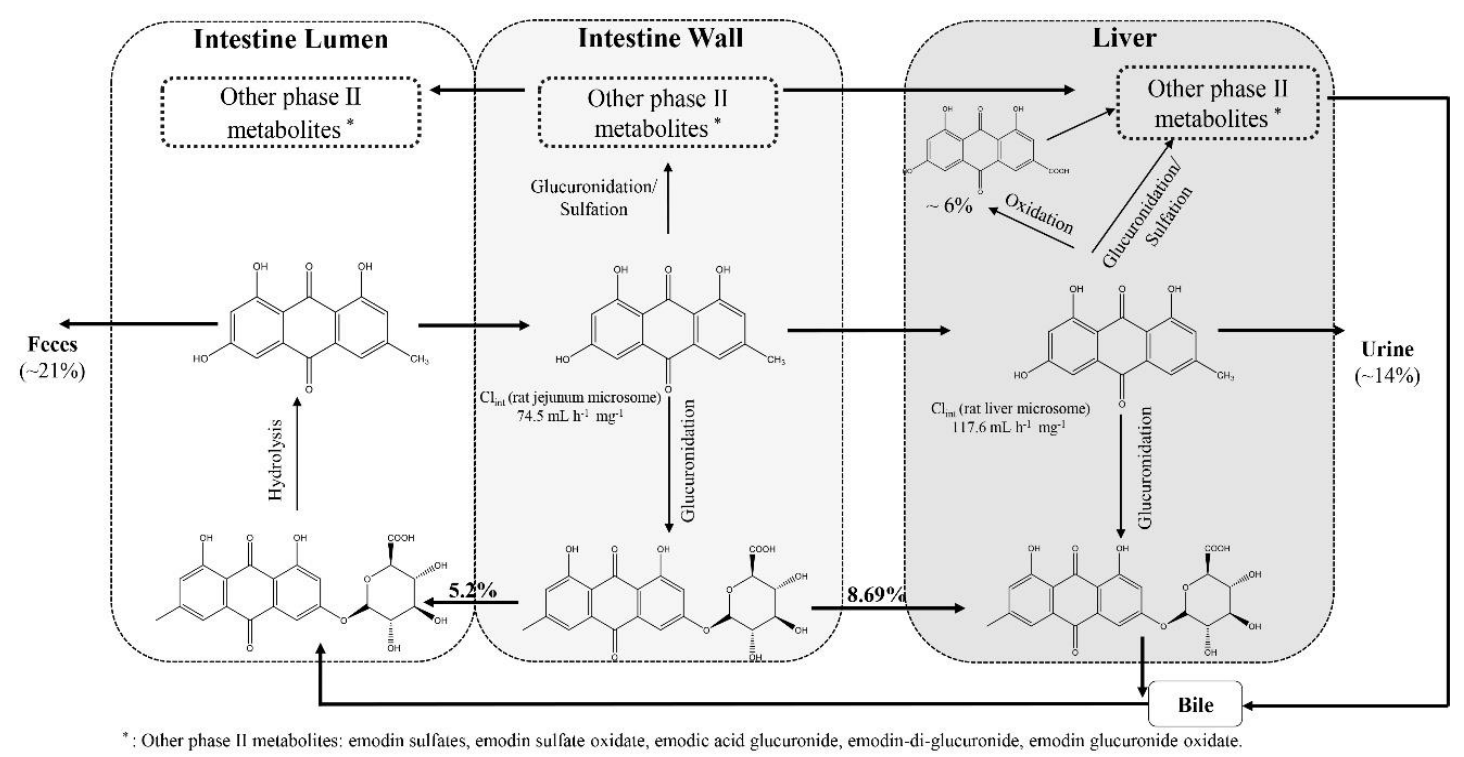

Figure 2. Illustrations of emodin metabolic pathways in rats.

Similar to emodin, both phase I and phase II metabolites were identified for physcion. After incubating physcion with liver microsomes, the oxidation and demethylation products of physcion were found [55]. After oral treatment of physcion to rats, besides oxidative metabolites of physcion, physcion $\mathrm{N}$-acetylcysteine conjugates, physcion sulfate, and physcion glucuronide were also detected. Moreover, recombinant human CYP1A2, 2C19, and 2B6 were demonstrated to be the primary enzymes mediating the hydroxylation of physcion [55].

\subsubsection{Elimination}

Among the three major RPM components, TSG eliminated the fastest with no detectable drug in rat tissues at $1 \mathrm{~h}$ and $3 \mathrm{~h}$ after its intravenous and oral administrations, respectively [35]. Bile excretion of TSG peaked at $2 \mathrm{~h}$ after intravenous administration, with cumulative excretion of TSG and TSG monoglucuronides at $0.1 \%$ and $5.8 \%$ of the dosage at $24 \mathrm{~h}$, respectively. The urinary and fecal cumulative excretion of unchanged TSG was $0.007 \%$ and $0.063 \% 24 \mathrm{~h}$ post-dosing, respectively. The quick elimination in rat tissues, low level of TSG in feces/urine, and high bile excretion of TSG monoglucuronides suggested its extensive biotransformation in the liver [35].

Similar to TSG, emodin is mainly excreted to bile, feces, and urine. After oral administration of $\left.10 \mathrm{mg} \mathrm{[}{ }^{14} \mathrm{C}\right]$ emodin to rats, $49 \%, 45.7 \%$, and $6.9 \%$ of the dose was excreted to bile, feces, and urine in its parent or metabolites form [47]. Among the excreted emodin in bile, conjugated emodin and emodic acid were much higher than their non-conjugated forms, further confirming the phase II metabolism in the liver as the major metabolic pathway.

Physcion was found to be mainly excreted as unchanged form via feces, with $13 \% \sim 21 \%$ recovered in feces at $72 \mathrm{~h}$ after oral administration of $18.7 \mathrm{mg} / \mathrm{kg}$ [48]. The urine excretion of physcion was rather limited, with less than $0.2 \%$ of the total dose found during the same period. So far, there is no report on the bile excretion of physcion.

\subsubsection{Effect of Co-Occurring Ingredients in RPM on the Pharmacokinetics of Emodin}

In addition to the above-mentioned ADME of each individual component in RPM, there are a number of studies that reported the potential interaction between the co-occurring ingredients in RPM. After comparing the pharmacokinetic parameters of TSG and emodin after oral administration of RPM extracts (Table 1) versus that obtained from their pure components (Table 2) in SD rats, it was noticed that the half-life values of TSG and emodin after oral administration of RPM extracts $(0.5 \sim 2 \mathrm{~h}$ for 
TSG, 1.5 3 $\mathrm{h}$ for emodin) are similar to that from their pure components ( $0.5 \mathrm{~h}$ for TSG, $3 \mathrm{~h}$ for emodin). However, the $\mathrm{C}_{\max }$ and AUC values of emodin after oral administration of RPM extracts (dose of emodin: $11.17 \mathrm{mg} / \mathrm{kg}$; AUC: $683.0 \pm 268.9 \mathrm{ng} \mathrm{h} / \mathrm{mL}, \mathrm{C}_{\max }: 224.5 \pm 131.1 \mathrm{ng} / \mathrm{mL}$ ) were higher than that from pure emodin $\left(10 \mathrm{mg} / \mathrm{kg}\right.$, AUC: $\left.420.3 \pm 48.1 \mathrm{ng} \mathrm{h} / \mathrm{mL}, \mathrm{C}_{\max }: 74.9 \pm 17.4 \mathrm{ng} / \mathrm{mL}\right)$ to SD rats, suggesting that systemic exposure of emodin could be affected by other co-occurring ingredients in RPM extract. It was found that the presence of TSG could significantly increase the $C_{\max }$ and AUC values of emodin via inhibiting its metabolism [34,56]. Moreover, the in vitro study also confirmed that TSG could increase the absorption of emodin via inhibiting its MRP mediated transport in Caco-2 cells and UDP glycosyltransferase-(UGT) mediated glucuronidation in human liver microsomes in a dose-dependent manner [57]. In addition to the influence of TSG, it was reported that the co-occurring anthraquinones components, including aloe-emodin, rhein, chrysophanol, and physcion, may lead to a decrease in emodin AUC in the cerebral ischemia-reperfusion model rats [58]. Overall, since the contents of these components are much lower than TSG in RPM [1,25], TSG may have the most significant influence on the change in emodin pharmacokinetics, which warrants further experimental verification.

In summary, the ADME characteristics of the major components in RPM, including TSG, emodin, and physcion, were well studied in rats and beagle dogs with fast absorption, and the elimination of TSG was faster than emodin followed by physcion. The transporters, such as SLTC1, P-glycoprotein, and MRP2, were involved in the absorption of TSG and emodin with glucuronidation as their major metabolic pathway. Additionally, TSG could increase the systemic exposure of emodin via increasing its absorption and inhibiting its metabolism in a dose-dependent manner. However, there is no information about the biodistribution of the major components of RPM after its extract treatment, which can offer a better understanding of the toxicity of RPM, especially hepatotoxicity.

\section{Hepatotoxicity}

\subsection{Case Reports on Liver Injury of RPM}

So far, there are several retrospective analysis studies investigating the clinical cases on RPM induced liver injury [59-61]. According to these studies, the common reasons for consuming RPM products included treating grey hair, hair loss, using it as a health supplement, or for the treatment of hypertension, coronary heart disease, hyperlipidemia, etc. In addition to proprietary products of RPM, decoction pieces processed with water, alcohol, or ground into powder were commonly used for oral administration in clinics. For all the patients from the above-mentioned case reports, the onset time for liver toxicity ranged from 1 to 240 days with a median of 30 days after oral administrations of RPM at doses ranging from $1 \mathrm{~g} /$ person/day to $100 \mathrm{~g} /$ person/day.

According to the Roussel Uclaf Causality Assessment Method, based on the type of damaged target cells, liver injury can be classified into three types, including hepatocyte liver injury, cholestatic liver injury, and their mixture type [62]. Most of the liver injuries induced by RPM were diagnosed as hepatocellular injury followed by mixed liver injury and cholestatic liver injury with jaundice, fatigue, anorexia as the major symptoms of RPM induced liver injury. Although RPM can induce liver injury in different degrees and even lead to death, the majority of RPM associated liver damage was found to be reversible after discontinuing RPM products and conservative care [59-61].

\subsection{Mechanistic Studies on Liver Injury Induced by RPM Extract and Its Major Components}

Since hepatic adverse effect reports on RPM had raised much concern for its safe use in clinics, a series of studies have been conducted to investigate the mechanisms of RPM associated liver injury. The findings are summarized in Table 3 with the major mechanisms highlighted below.

\subsubsection{Metabolic Enzymes Alteration and Genetic Polymorphism}

It was found that altered metabolic enzymes, such as CYP and UGT, were proved to contribute to RPM induced liver injury. The protein expression of drug metabolic enzymes, including CYP2A, 
CYP3A4, CYP2C19, CYP2E1, UGT1A1, and UGT1A8, was inhibited while the ALT and AST increased after oral administration of RPM extracts to rats [31]. In CYP1A2 or CYP2E1 inhibitors-treated rats, RPM could significantly increase the level of serum transaminases ALT and AST and induce moderate liver injury [63]. In addition, according to the clinical studies, the liver injury induced by RPM may be related to the polymorphism of CYP. CYP1A2, which account for 13\% of total CYP enzymes in human [64], exhibits genetic polymorphism in the population, and CYP1A2*1C frequency $(46.5 \%)$ in RPM induced liver injury Chinese patients was found to be significantly higher than that in healthy volunteers (27.9\%) [65]. As the major absorbable component of RPM, emodin (greater than 6\% of the dose) could undergo phase I metabolism with CYP1A2 as the major metabolic enzyme in rats [54]. Thus, the altered CYP1A2 mediated metabolism of emodin may attribute to RPM induced liver injury. In addition to CYP1A2 polymorphism in humans, it was found that RPM induced liver injury might be a type of immune-mediated idiosyncratic liver injury, and the frequency of the HLA-B*35:01 allele was much higher in RPM induced liver injury patients (45.4\%) than healthy Han Chinese population $(2.7 \%)[66]$.

Overall, the altered metabolic enzymes, including CYP and UGT, as well as HLA-B*35:01 allele, are considered to be high-risk factors for RPM induced liver injury.

\subsubsection{Hepatocytes Apoptosis}

Apoptosis is defined morphologically on the basis of cellular rounding up, cytoplasmic shrinkage, chromatin condensation, and nuclear fragmentation [67]. Effector caspase activation is required for the acquisition of this morphology. As the most numerous cell type in the liver, the apoptosis of hepatocytes is prominent in liver injury [67]. Apoptosis shares common cell death machinery, including death receptor-dependent and mitochondria-dependent pathways [68]. As the major anthraquinone in RPM, emodin could induce liver damage via the mitochondrial pathway [69-71]. Yang et al. found that emodin could induce mitochondrial apoptosis and lead to liver injury with protein expression of caspase-9, caspase-3, and cytochrome c (Cyt c) increasing after treating the rats with emodin $(1500 \mathrm{mg} / \mathrm{kg})$ for one week [69]. Similar results were observed in the L02 cell line; that $50 \mu \mathrm{M}$ emodin could affect oxidative phosphorylation pathways by inhibiting the function of the mitochondrial respiratory chain complexes, leading to mitochondrial damage and hepatocyte apoptosis in vitro [70]. In addition, emodin at $20-80 \mu \mathrm{M}$ was found to block cell cycle progression and generate reactive oxygen species in HepaRG cells, leading to abrogated mitochondrial membrane potential and cell apoptosis via mitochondrial apoptosis pathway [71].

\subsubsection{Disruption of Bile Acids Homeostasis}

Currently, bile acids have been demonstrated to play essential roles in drug-induced liver injury [72] According to the clinical case reports about RPM induced liver injury, besides the hepatocellular injury induced by RPM, many cases of RPM associated liver injury were classified as cholestatic liver injury, suggesting a correlation between bile acids and RPM induced liver injury. The preclinical investigations in cell lines, mice, and rats indicated that RPM and its major anthraquinones could alter the disposition of bile acids at different degrees via regulating bile acid synthesis or transport [73-78].

RPM could alter the biosynthesis of bile acids. In mice, after oral administration of 1.275 and $3.825 \mathrm{~g} / \mathrm{kg}$ RPM extract of processed RPM for 7 days, the bile acids levels in hepatocytes decreased, followed by the downregulation in the protein expression of CYP7A1, the key enzyme involved in bile acids synthesis [77]. After consecutively administrating 30 and $60 \mathrm{~g} / \mathrm{kg}$ RPM extracts to rats for 28 days or $20 \mathrm{~g} / \mathrm{kg}$ RPM extracts for 90 days, the protein expression of CYP7A1 was upregulated [73,74]. Such discrepancy in CYP7A1 regulation could be due to different animal species, different doses and duration of RPM treatment, which warrants further verification.

Besides influencing the biosynthesis of bile acids, RPM could also disturb the bile acid homeostasis via regulating the expression of bile acid transporters. The mRNA expression of sodium taurocholate cotransporting polypeptide (Ntcp), the major uptake transporter of bile acids, could be upregulated 
after one-week of oral administrations of $3.825 \mathrm{~g} / \mathrm{kg}$ RPM extract to mice [77] and downregulated after oral administration of $20 \mathrm{~g} / \mathrm{kg}$ RPM extracts for 3 to 7 weeks in rats [75]. Besides, the mRNA/protein expression levels of bile salt export pump (BSEP/Bsep) [74,75,77] and Mrp2/3 [74], the major efflux transporters for bile acids, were elevated after oral RPM extract treatment in mice $(3.825 \mathrm{mg} / \mathrm{kg}$ for 7 days) [77] or rats (20-60 g/kg for up to 7 weeks) [74,75]. Moreover, mRNA and protein expression levels of farnesoid X receptor (FXR), which controls bile synthesis and transport, were inhibited after oral administration of $30 \mathrm{~g} / \mathrm{kg}$ or $60 \mathrm{~g} / \mathrm{kg}$ RPM extract for 28 days in rats [74]. Since the disruption of bile acids synthesis and transport, the balance of the bile acid pool could be disrupted. Therefore, glycochenodeoxycholic acid (GCDCA) in bile [76], hyodeoxycholic acid (HDCA) in serum [75,76], as well as tauro- $\beta$-muricholic acid (T $\beta$ MCA) in urine [75] were suggested to be potential biomarkers for RPM induced liver injury in rats.

Furthermore, the in vitro study revealed that anthraquinones from RPM, including emodin, chrysophenol, and physcion, could alter the disposition of bile acids in sandwich cultured rat hepatocytes. Anthraquinones, including emodin, physcion, and chrysophanol, could significantly increase the total bile acids in the cells and bile duct at $25 \mu \mathrm{M}$ and inhibit the basolateral efflux of bile acids at $50 \mu \mathrm{M}$ [78]. Additionally, emodin and physcion at $50 \mu \mathrm{M}$ could significantly inhibit the function of MRP2/3 and BSEP as well as regulating the mRNA expression of bile acids synthesis enzymes, transporters, including Cyp7a1, Cyp27a1, Cyp8b1, Ntcp, Mrp2/3/4, and Bsep, in sandwich cultured rat hepatocytes [78]. Since physcion and chrysophanol were almost undetectable after oral administration of RPM extracts, emodin, the major in vivo detectable component from RPM, could be considered as the main component contributing to the disruption of bile acids induced by RPM.

In summary, RPM extract could disturb the bile acid pool via regulating bile acid synthesis enzyme expression or affecting the function or expression of bile acid transporters. Several bile acids, such as GCDCA, HDCA, and T $\beta M C A$, were suggested to be potential biomarkers for RPM induced liver injury, which offers a foundation for the safe use of RPM in the clinic. Emodin, the major bioavailable anthraquinone in RPM, plays an important role in RPM induced bile acids homeostasis.

\subsubsection{Inflammatory Damage}

Besides the mechanisms mentioned above, the inflammation response has an important effect on RPM induced liver injury. It was also found that emodin could induce inflammatory liver damage in vivo and in vitro. In lipopolysaccharide (LPS) treated rats, which was considered as idiosyncratic liver injury model, emodin at doses ranging from 20 to $80 \mathrm{mg} / \mathrm{kg}$ could significantly increase the level of plasma proinflammatory cytokines, such as TNF- $\alpha$, IL- $1 \beta$, and IL-6, as well as the level of AST and ALT [79]. Additionally, emodin could significantly increase the level of p-NF-kB and IL-6, which induce inflammatory damage in the L02 cell line in a dose-dependent manner [80]. 
Table 3. Summary of reported clinical and preclinical liver injury mechanisms of RPM and its components.

\begin{tabular}{|c|c|c|c|c|}
\hline Mechanisms & Model & Substance & Dose/Duration & Findings \\
\hline \multirow{4}{*}{$\begin{array}{l}\text { Metabolic enzymes alteration } \\
\text { and genetic polymorphism }\end{array}$} & SD rats [31] & RPM extract & $6 \mathrm{~g}$ raw $\mathrm{RPM} / \mathrm{kg} /$ bolus & $\begin{array}{c}\text { Protein expression: CYP3A4, CYP2C19, CYP2E1, UGT1A1 } \\
\text { and UGT1A8 } \downarrow ; \text {; ALT and AST } \uparrow .\end{array}$ \\
\hline & SD rats [63] & RPM aqueous extract & 40 g raw $\mathrm{RPM} / \mathrm{kg} / 3$ weeks & $\begin{array}{l}\text { CYP1A2 or CYP2E1 inhibitors + RPM: ALT and AST } \uparrow \\
\text { moderate liver injury. }\end{array}$ \\
\hline & $\begin{array}{c}\text { Human } \\
\text { (43 cases) }[65]\end{array}$ & RPM & NR & $\begin{array}{l}\text { CYP1A2*1C frequency: } 46.5 \% \text { : RPM induced liver injury } \\
\text { patients; } 27.9 \% \text { : healthy controls. }\end{array}$ \\
\hline & $\begin{array}{c}\text { Human } \\
\text { (87 cases) }[66]\end{array}$ & RPM & 4 weeks & $\begin{array}{l}\text { HLA-B*35:01 allele: } 45.4 \% \text { : RPM induced liver injury } \\
\text { patients; } 2.7 \% \text { : Han Chinese population. }\end{array}$ \\
\hline \multirow{3}{*}{ Hepatocytes apoptosis } & SD rats [69] & Emodin & $1500 \mathrm{mg} / \mathrm{kg} / 7$ days & $\begin{array}{c}\text { Emodin: } \uparrow \text { caspase- } 9 \text {, caspase- } 3 \text {, and Cyt } \mathrm{c} \rightarrow \text { mitochondrial } \\
\text { apoptosis and liver injury }\end{array}$ \\
\hline & L02 cells [70] & Emodin & $50 \mu \mathrm{M}$ & $\begin{array}{c}\text { Emodin: } \uparrow \text { caspase- } 3 \text { and ROS, } \downarrow \text { mitochondrial membrane } \\
\text { potential, disrupting ATP synthesis } \rightarrow \text { mitochondrial } \\
\text { damage and hepatocyte apoptosis. }\end{array}$ \\
\hline & HepaRG cells [71] & Emodin & $20-80 \mu \mathrm{M}$ & $\begin{array}{c}\text { Emodin: cell cycle arrest and ROS generation } \rightarrow \\
\text { mitochondrial apoptosis } \rightarrow \text { cell apoptosis. }\end{array}$ \\
\hline \multirow[b]{3}{*}{$\begin{array}{l}\text { Bile acids homeostasis } \\
\text { disruption }\end{array}$} & SD rats [73] & Extracts of raw RPM (75\% EtOH) & 1 and $20 \mathrm{~g}$ extract $/ \mathrm{kg} / 90$ days & $\begin{array}{l}\text { Protein expression of 3-hydroxy-3-methylglutaryl CoA } \\
\text { reductase and CYP7A1 } \uparrow \text { in a dose-dependent manner. }\end{array}$ \\
\hline & SD rats [74] & RPM concentrated powder $(1: 10)$ & 30 and $60 \mathrm{~g}$ extract $/ \mathrm{kg} / 28$ days & $\begin{array}{c}\text { mRNA and protein expression of MRP2/Mrp2, MRP3/Mrp3, } \\
\text { BSEP/Bsep, FXR/Fxr, CYP7A1/Cyp7a1 } \uparrow .\end{array}$ \\
\hline & SD rats [75] & Extracts of raw RPM (75\% EtOH) & 1 and $20 \mathrm{~g}$ extract $/ \mathrm{kg} / 3,6,7$ weeks & $\begin{array}{l}\text { - HDCA, CA, TUDCA, and DCA in serum, T } \beta \text { MCA, } \\
\text { TCA, CA, and } \beta \text { MCA in urine } \uparrow \text { in a dose- and } \\
\text { time-dependent manner; } \\
\text { - HDCA in serum and T } \beta \text { MCA in urine were identified } \\
\text { as potential biomarkers for RPM induced liver injury; } \\
\text { - The mRNA expression of Bsep } \uparrow \text { and Ntcp } \downarrow \text { in liver. }\end{array}$ \\
\hline
\end{tabular}


Table 3. Cont.

\begin{tabular}{|c|c|c|c|c|}
\hline Mechanisms & Model & Substance & Dose/Duration & Findings \\
\hline & SD rats $[76]$ & $\begin{array}{l}\text { Extracts of } \\
\text { raw and processed RPM (75\% EtOH) }\end{array}$ & $50 \mathrm{~g}$ extract $/ \mathrm{kg} / 42$ days & $\begin{array}{l}\text { GDCA in bile, as well as HDCA in serum, could be selected } \\
\text { as potential biomarkers for RPM induced liver injury. }\end{array}$ \\
\hline & C57BL/6J mice [77] & Extracts of processed RPM $(60 \% \mathrm{EtOH})$ & 1.275 and $3.825 \mathrm{~g}$ extract $/ \mathrm{kg} / 7$ days & $\begin{array}{l}\text { - Total bile acids } \downarrow \text { in liver and serum, unconjugated BAs } \\
\uparrow \text { in intestines; } \\
\text { - } \quad \text { mRNA expression: Nctp and Bsep } \uparrow \text {; protein expression } \\
\text { of CYP7A1 } \downarrow \text {. }\end{array}$ \\
\hline & $\begin{array}{l}\text { Sandwich cultured rat } \\
\text { hepatocytes [78] }\end{array}$ & Emodin, Physcion, Chrysophanol & $1-50 \mu \mathrm{M}$ & $\begin{array}{l}\text { All compounds could alter bile acids disposition through } \\
\text { direct } \downarrow \text { BA transporters as well as regulated expression of } \\
\text { bile acids transporters and metabolic enzymes. }\end{array}$ \\
\hline \multirow{2}{*}{ Inflammatory damage } & SD rats [79] & Emodin & $20,40,80 \mathrm{mg} / \mathrm{kg}$ & $\begin{array}{c}\text { Emodin + lipopolysaccharide: } \uparrow \text { proinflammatory cytokines } \\
(\text { TNF- } \alpha \text {, IL- } 1 \beta \text { and IL- } 6) \rightarrow \text { ALT and AST } \uparrow .\end{array}$ \\
\hline & L02 cells [80] & Emodin & $10.93,54.09,267.7 \mu \mathrm{M}$ & Emodin: $\uparrow$ p-NF-kB and IL-6 $\rightarrow$ inflammatory damage. \\
\hline
\end{tabular}




\subsection{Correlations between Pharmacokinetics of RPM and Its Induced Liver Injury}

Similar to western drugs, RPM could exhibit therapeutic windows with toxicities identified at higher doses [81]. It was reported that RPM extract could attenuate liver cirrhosis induced by dimethylnitrosamine in mice at the dose of $20-100 \mathrm{mg} / \mathrm{kg} / \mathrm{day}$ (equal to $0.093-0.465 \mathrm{~g}$ raw RPM $/ \mathrm{kg} /$ day), while such therapeutic effect decreased and toxic effects were observed with the dose increasing to $500 \mathrm{mg} / \mathrm{kg} /$ day (equal to $2.326 \mathrm{~g}$ raw $\mathrm{RPM} / \mathrm{kg} /$ day) [7]. A similar trend was also observed for emodin in rats with liver protection from $\mathrm{CCl}_{4}$-induced fibrogenesis after its oral administration at $40 \mathrm{mg} / \mathrm{kg} /$ day [82] and liver damage induced after its oral administration at $1500 \mathrm{mg} / \mathrm{kg}$ [69]. Moreover, Ma et al. indicated that the gradual increased in vivo exposure of emodin after oral administration of RPM extract ( $20 \mathrm{~g}$ raw RPM/kg) for 21 days might contribute to the RPM-induced hepatic lesions [33]. Therefore, it is speculated that the therapeutic and toxic effects of RPM could be correlated with the dose and in vivo level of emodin.

It is noticed that the maximum concentration of emodin in the rat plasma ranged from $61.29 \mathrm{ng} / \mathrm{mL}$ to $348.10 \mathrm{ng} / \mathrm{mL}$ after oral administration of RPM extract at doses ranging from $6 \mathrm{~g} / \mathrm{kg}$ to $40 \mathrm{~g} / \mathrm{kg}$. Such concentration is far below $20 \mu \mathrm{M}$ (or $54 \mu \mathrm{g} / \mathrm{mL}$ ), the minimum concentration of emodin observed in the in vitro liver toxicity study in human L02 and HepaRG cells [70,71] and rat sandwich cultured hepatocyte [78]. Shi et al. reported a much higher concentration of emodin in the liver $(940.12 \mathrm{ng} / \mathrm{g})$ than that in the plasma $(120.98 \mathrm{ng} / \mathrm{ml})$ after oral administration of $10 \mathrm{mg} / \mathrm{kg}$ emodin loaded nanoemulsion in rats [38]. Although its human liver concentration remains unknown, emodin is expected to have a higher accumulation in the liver than in plasma, leading to potential liver toxicity.

In addition to the above-mentioned liver toxicity of emodin itself, the co-occurring components in RPM could also affect its in vivo levels leading to enhanced liver toxicity. Although both CYP1A2 and UGT1A8 were involved in the metabolism of emodin in rats, UGT mediated phase II metabolism is the dominant metabolic pathway of emodin. After consecutively treating with TSG (117 mg/kg) for 7 days, a decrease in the mRNA expression of Ugt1a8 in rat liver and intestine led to increased $\mathrm{C}_{\max }$ and AUC of emodin in rats [34], and the metabolism of emodin could be inhibited by TSG in the human liver microsome in a dose-dependent manner [57]. Moreover, the absorption of emodin could be increased in the Caco- 2 cell in the presence of TSG. Such increased systemic exposure of emodin by TSG may further contribute to the RPM induced liver injury. According to the existing Pharmacopeia, only the lower limits for the contents of TSG and emodin in RPM were required. However, the impact of RPM with different contents of TSG on the in vivo concentrations of emodin and its related liver damage is not clear so far. Therefore, the relevant upper limits of the content of TSG and emodin in RPM, and the relationship with its induced liver toxicity need further clarification.

Toxicokinetics is usually adopted to determine the relationship between the systemic exposure of a compound and its toxicity in animals and humans. To achieve the toxicokinetics of herbal medicines, such as RPM, we need to determine the exposure of its major bioavailable components in blood and major organs and the relationship with its induced liver toxicity. Since there is no information about the concentrations of the major components of RPM in the liver after oral administration of its extract, detailed biodistributions (especially liver concentrations) of RPM major components in preclinical animal studies should first be obtained to better understand the in vivo levels of these components, including TSG and emodin, and how they correlate with the RPM induced liver injury.

\subsection{Role of Herb-Drug/Herb Interactions in RPM Induced Liver Injury}

Herb-drug/herb interactions are of great concern when patients concomitantly take drugs and herbs, especially taking herbal and western medicines at the same time. Since emodin was the major component contributing to liver toxicity of RPM, the interaction of emodin in RPM with other drugs/herbs could be critical to the safe use of RPM in the clinic.

It was noted that emodin induced hepatotoxicity at $150 \mathrm{mg} / \mathrm{kg}$ could be further enhanced by probenecid $(100 \mathrm{mg} / \mathrm{kg})$ due to increased systemic exposure of emodin resulted from its inhibition on UGTs and MRP2 in rats [83]. In addition, piperine, the bioactive compound of Piper nigrum L. 
and Piper longum L., could significantly increase the AUC and $\mathrm{C}_{\max }$ of emodin via the inhibition of its glucuronidation [84]. Therefore, people should pay more attention to hepatotoxicity when they take emodin-containing herbal medicine together with drugs/herbs that could inhibit the expression or activity of UGT or MRP2. On the other hand, the herb-herb interaction may attenuate the RPM induced liver injury. A recent study found that combined use of Poria and RPM could significantly ameliorate the RPM-induced liver injury and systemic inflammation in LPS treated rats [85]. Since emodin could also induce liver injury in LPS treated rats with significantly increased proinflammatory cytokines [71], the above-mentioned detoxification effects of Poria could be related to its influence on emodin leading to a reduction in corresponding inflammatory cytokines, which warrants further verification.

\section{Conclusions}

In summary, plasma pharmacokinetic profiles of RPM and its major components have been investigated in various preclinical models, while the possible mechanisms of its induced liver injury have also been explored in the clinic as well as different preclinical models. Based on the evidenced liver toxicity of emodin, it was suggested that emodin was the major component attributed to RPM liver injury, and the co-occurring ingredient TSG could increase the exposure of emodin via inhibition of its phase II metabolism, leading to enhanced liver toxicity via hepatocyte apoptosis, disturbing bile acids homeostasis, and inflammatory damage. Besides, other major co-occurring anthraquinones components, including aloe-emodin, rhein, chrysophanol, and physcion, as well as herb-drug/herb interaction with RPM, also play important roles in its induced liver injury.

To further understand the impact of emodin in vivo levels on the RPM induced liver injury, its biodistributions in major organs, including plasma and liver, after oral administration of RPM extract should be evaluated to establish its toxicokinetics. In addition, the effect of contents of co-occurring components in RPM or other co-administered detoxification herbs on the in vivo levels of emodin and related liver toxicity is also worth further exploration. Based on the established toxicokinetics of emodin in animals, physiological toxicokinetic models could be adopted to describe and predict the behavior of emodin in humans, as suggested before [86]. Thus, clinical monitoring of its level in biomatrix could serve as an approach for the prevention and/or early diagnosis of RPM-induced liver injury in future clinical practice.

Author Contributions: Conceptualization: Z.Z. and D.L.; writing and review: Z.Z. and D.L.; literature researching: D.L. and M.Y. All authors have read and agreed to the published version of the manuscript.

Funding: This research received no external funding.

Conflicts of Interest: The authors declare no conflict of interest.

$\begin{array}{ll}\text { Abbreviations } \\ \text { AUC } & \text { Area under the concentration-time curve } \\ \text { ADME } & \text { Absorption, distribution, metabolism and elimination } \\ \text { BSEP } & \text { Bile salt export pump } \\ \text { C }_{\max } & \text { Peak concentration } \\ \text { CL }_{\text {int }} & \text { Intrinsic clearance } \\ \text { CYP } & \text { Cytochrome P450 } \\ \text { Cyt c } & \text { Cytochrome c } \\ \text { EMG } & \text { Emodin- } 8-O-\beta \text {-D-glucopyranoside } \\ \text { FXR } & \text { Farnesoid X receptor } \\ \text { GCDCA } & \text { Glycochenodeoxycholic acid } \\ \text { HLA } & \text { Human leukocyte antigen } \\ \text { HDCA } & \text { Hyodeoxycholic acid } \\ K_{a} & \text { Absorption rate constant } \\ \text { LPS } & \text { Lipopolysaccharide } \\ \text { MRP } & \text { Multidrug resistance-associated protein }\end{array}$




$\begin{array}{ll}\text { NTCP } & \text { Sodium taurocholate co-transporting polypeptide } \\ \mathrm{P}_{\text {app }} & \text { Apparent permeability coefficient } \\ \mathrm{P}_{\text {eff }} & \text { Effective intestinal permeability } \\ \text { RPM } & \text { Radix Polygoni Multiflori } \\ \text { SGLT1 } & \mathrm{Na}^{+} / \text {glucose cotransporter } \\ \text { TSG } & 2,3,5,4^{\prime} \text {-tetrahydroxystilbene-2-O- } \beta \text {-D-glucopyranoside } \\ \mathrm{T}_{\max } & \text { Time to maximum plasma concentration } \\ \text { T } \beta \text { MCA } & \text { Tauro- } \beta \text {-muricholic acid } \\ \text { UGT } & \text { UDP glycosyltransferase }\end{array}$

\section{References}

1. Chinese Pharmacopeia Commission. Chinese Pharmacopoeia; China Medical Science Press: Beijing, China, 2009; Volume 75, pp. 175-177. [CrossRef]

2. Lin, H.; Ho, M.T.; Lau, L.S.; Wong, K.K.; Shaw, P.; Wan, D.C. Anti-acetylcholinesterase activities of traditional Chinese medicine for treating Alzheimer's disease. Chem. Interact. 2008, 175, 352-354. [CrossRef] [PubMed]

3. Chen, W.S.; Xu, J.P.; Li, L.; Qiao, C. Studies on nootropic activity and mechanism of emodin-8-O-ß-d-glucopyranoside. Chin. Tradit. Herb. Drugs 2001, 32, 39-41.

4. Zhang, Q.; Xu, Y.; Zou, S.; Zhang, X.; Cao, K.; Fan, Q. Novel functional polysaccharides from Radix Polygoni Multiflori water extracted residue: Preliminary characterization and immunomodulatory activity. Carbohydr. Polym. 2016, 137, 625-631. [CrossRef]

5. Chen, Q.; Zhang, S.-Z.; Ying, H.-Z.; Dai, X.-Y.; Li, X.-X.; Yu, C.; Ye, H.-C. Chemical characterization and immunostimulatory effects of a polysaccharide from Polygoni Multiflori Radix Praeparata in cyclophosphamide-induced anemic mice. Carbohydr. Polym. 2012, 88, 1476-1482. [CrossRef]

6. Lou, Z.; Xia, B.; Su, J.; Yuefang, H.; Yan, M.; Huang, Y.; Lv, G. Effect of a stilbene glycoside-rich extract from Polygoni Multiflori Radix on experimental non-alcoholic fatty liver disease based on principal component and orthogonal partial least squares discriminant analysis. Exp. Ther. Med. 2017, 14, 4958-4966. [CrossRef]

7. Huang, C.-H.; Horng, L.-Y.; Chen, C.-F.; Wu, R.-T. Chinese herb Radix Polygoni Multiflori as a therapeutic drug for liver cirrhosis in mice. J. Ethnopharmacol. 2007, 114, 199-206. [CrossRef]

8. Zhu, W.; Xue, X.; Zhang, Z. Ultrasonic-assisted extraction, structure and antitumor activity of polysaccharide from Polygonum multiflorum. Int. J. Biol. Macromol. 2016, 91, 132-142. [CrossRef]

9. Cha, D.S.; Jeon, H. Anti-inflammatory effect of $\mathrm{MeOH}$ extracts of the stem of Polygonum multiflorum in LPS-stimulated mouse peritoneal macrophages. Nat. Prod. Sci. 2009, 15, 83-89.

10. But, P.P.; Tomlinson, B.; Lee, K.L. Hepatitis related to the Chinese medicine Shou-wu-pian manufactured from Polygonum multiflorum. Vet. Hum. Toxicol. 1996, 38, 280-282.

11. Park, G.J.-H.; Mann, S.P.; Ngu, M.C. Acute hepatitis induced by Shou-Wu-Pian, a herbal product derived from Polygonum multiflorum. J. Gastroenterol. Hepatol. 2001, 16, 115-117. [CrossRef] [PubMed]

12. Cárdenas, A.; Restrepo, J.C.; Sierra, F.; Correa, G. Acute Hepatitis Due to Shen-Min. J. Clin. Gastroenterol. 2006, 40, 629-632. [CrossRef] [PubMed]

13. Laird, A.R.; Ramchandani, N.; Degoma, E.M.; Avula, B.; Khan, I.A.; Gesundheit, N. Acute Hepatitis Associated With the Use of an Herbal Supplement (Polygonum Multiflorum) Mimicking Iron-overload Syndrome. J. Clin. Gastroenterol. 2008, 42, 861-862. [CrossRef] [PubMed]

14. Cho, H.C.; Min, H.J.; Ha, C.Y.; Kim, H.J.; Kim, T.H.; Jung, W.-T.; Lee, O.J.; Bae, I.-G. Reactivation of Pulmonary Tuberculosis in a Patient with Polygonum multiflorum Thunb-Induced Hepatitis. Gut Liver 2009, 3, 52-56. [CrossRef] [PubMed]

15. Jung, K.A.; Min, H.J.; Yoo, S.S.; Kim, H.J.; Choi, S.N.; Ha, C.Y.; Kim, H.J.; Kim, T.H.; Jung, W.T.; Lee, O.J.; et al. Drug-Induced Liver Injury: Twenty Five Cases of Acute Hepatitis Following Ingestion of Polygonum multiflorum Thunb. Gut Liver 2011, 5, 493-499. [CrossRef]

16. Dong, H.; Slain, D.; Cheng, J.; Ma, W.; Liang, W. Eighteen cases of liver injury following ingestion of Polygonum multiflorum. Complement. Ther. Med. 2014, 22, 70-74. [CrossRef]

17. Canadian Adverse Reaction Newsletter, 2003. Case presentation: RespirActin. Available online: http: //www.hc-sc.gc.ca/dhp-mps/medeff/bulletin/carn-bcei_v13n1-eng.php (accessed on 6 January 2003). 
18. Complementary Medicines Evaluation Committee (CMEC) A. Polygonum Multiflorum May Harm the Liver in Some People (Updated 2008). Available online: http://www.tga.gov.au/archive/labelling-rasml-notices080414.htm (accessed on 23 April 2008).

19. Medicines and Healthcare products Regulatory Agency (MHRA). MHRA Raises Concerns about the Safety of Polygonum Multiflorum (Updated 2006). Available online: https://www.who.int/medicines/publications/ newsletter/pn2006_3.pdf?ua=1 (accessed on 28 April 2006).

20. China Food and Drug Administration (CFDA). CFDA reminds about the risk of liver injury induced by oral assumption of PMR (Updated 2014). Available online: https://www.nmpa.gov.cn/yaopin/ypjgdt/ 20140716145801865.html (accessed on 16 July 2014).

21. National Toxicology Program. NTP Toxicology and Carcinogenesis Studies of EMODIN (CAS NO. 518-82-1) Feed Studies in F344/N Rats and B6C3F1 Mice. Natl. Toxicol. Program Tech. Rep. Ser. 2001, 493, 1-278. [PubMed]

22. Lin, L.; Ni, B.; Lin, H.; Zhang, M.; Li, X.; Yin, X.; Qu, C.; Ni, J. Traditional usages, botany, phytochemistry, pharmacology and toxicology of Polygonum multiflorum Thunb.: A review. J. Ethnopharmacol. 2015, 159, 158-183. [CrossRef]

23. Feng, Y.U.; Bounda, G.-A. Review of clinical studies of Polygonum multiflorum Thunb. and its isolated bioactive compounds. Pharmacogn. Res. 2015, 7, 225-236. [CrossRef]

24. Liu, Y.; Wang, Q.; Yang, J.; Guo, X.; Liu, W.; Ma, S.; Li, S. Polygonum multiflorum Thunb.: A Review on Chemical Analysis, Processing Mechanism, Quality Evaluation, and Hepatotoxicity. Front. Pharmacol. 2018, 9, 364. [CrossRef]

25. Wang, L.; Sang, M.; Liu, E.; Banahene, P.O.; Zhang, Y.; Wang, T.; Han, L.; Gao, X. Rapid profiling and pharmacokinetic studies of major compounds in crude extract from Polygonum multiflorum by UHPLC-Q-TOF-MS and UPLC-MS/MS. J. Pharm. Biomed. Anal. 2017, 140, 45-61. [CrossRef]

26. Yao, S.; Li, Y.; Kong, L. Preparative isolation and purification of chemical constituents from the root of Polygonum multiflorum by high-speed counter-current chromatography. J. Chromatogr. A 2006, 1115, 64-71. [CrossRef] [PubMed]

27. Zhang, L.; Ma, W.-F.; Li, J.; He, J.; Zhang, P.; Zheng, F.; Zhang, B.-L.; Gao, X.; Chang, Y.-X. Influence of processing on pharmacokinetic of typical constituents in radix polygoni multiflori after oral administration by LC-ESI-MS/MS. J. Ethnopharmacol. 2013, 148, 246-253. [CrossRef] [PubMed]

28. Liang, Z.; Chen, H.-B.; Yu, Z.-L.; Zhao, Z. Comparison of raw and processed Radix Polygoni Multiflori (Heshouwu) by high performance liquid chromatography and mass spectrometry. Chin. Med. 2010, 5, 29. [CrossRef] [PubMed]

29. Hong Kong Chinese Materia Medica Standards V. Available online: http://www.cmd.gov.hk/hkcmms/vol2/ main.html (accessed on 1 July 2008).

30. Cheng, W.; Li, Y.; Yang, W.; Wu, S.; Wei, M.; Gao, Y.; Kang, C.; Zhang, S.-F.; Li, Y. Simultaneous Determination of 13 Constituents of Radix Polygoni Multiflori in Rat Plasma and Its Application in a Pharmacokinetic Study. Int. J. Anal. Chem. 2020, 2020, 1-10. [CrossRef] [PubMed]

31. Zhang, M.; Lin, L.; Lin, H.; Qu, C.; Yan, L.; Ni, J. Interpretation the Hepatotoxicity Based on Pharmacokinetics Investigated Through Oral Administrated Different Extraction Parts of Polygonum multiflorum on Rats. Front. Pharmacol. 2018, 9, 505. [CrossRef]

32. Lin, L.; Ni, B.; Lin, H.; Cao, S.; Yang, C.; Zhao, Y.; Xue, D.; Ni, J. Simultaneous determination and pharmacokinetic study of P-hydroxybenzaldehyde, 2,3,5,4'-tetrahydroxystilbene-2-O- $\beta$-glucoside, emodin-8-O- $\beta$-d-glucopyranoside, and emodin in rat plasma by liquid chromatography tandem mass spectrometry after oral administration of Polygonum multiflorum. Anal. Methods 2015, 7, $244-252$. [CrossRef]

33. Ma, J.; Zheng, L.; He, Y.-S.; Li, H.-J. Hepatotoxic assessment of Polygoni Multiflori Radix extract and toxicokinetic study of stilbene glucoside and anthraquinones in rats. J. Ethnopharmacol. 2015, 162, 61-68. [CrossRef]

34. Ma, J.; Zheng, L.; Deng, T.; Li, C.-L.; He, Y.-S.; Li, H.-J.; Li, P. Stilbene glucoside inhibits the glucuronidation of emodin in rats through the down-regulation of UDP-glucuronosyltransferases 1A8: Application to a drug-drug interaction study in Radix Polygoni Multiflori. J. Ethnopharmacol. 2013, 147, 335-340. [CrossRef] 
35. Zhao, Y.; Zhang, L.; Feng, Y.; Chen, D.Q.; Xi, Z.H.; Du, X.; Bai, X.; Lin, R. Pharmacokinetics of 2,3,5,4'-tetrahydroxystilbene-2-O-beta-D-glucoside in rat using ultra-performance LC-quadrupole TOF-MS. J. Sep. Sci. 2013, 36, 863-871. [CrossRef]

36. Liu, W.; Zheng, Z.; Liu, X.; Gao, S.; Ye, L.; Yang, Z.; Hu, M.; Liu, Z. Sensitive and robust UPLC-MS/MS method to determine the gender-dependent pharmacokinetics in rats of emodin and its glucuronide. J. Pharm. Biomed. Anal. 2011, 54,1157-1162. [CrossRef]

37. Chen, J. Pharmacokinetics of oral administration of 2,3,5,4'-tetrahydroxystilbene-2-O- $\beta$-d-glucoside from Polygonum multiflorum in beagle dogs. Afr. J. Pharm. Pharmacol. 2012, 6. [CrossRef]

38. Shi, Y.; Li, J.; Ren, Y.; Wang, H.; Cong, Z.; Wu, G.; Du, L.; Li, H.; Zhang, X. Pharmacokinetics and tissue distribution of emodin loaded nanoemulsion in rats. J. Drug Deliv. Sci. Technol. 2015, 30, 242-249. [CrossRef]

39. Cai, J.Z.; Chen, S.H.; Zhang, Q.W.; Zhuang, R. Determination of Emodin in Rat Plasma by Gradient Elution LC-ESI-MS and its Application to Pharmacokinetics. Lat. Am. J. Pharm. 2013, 32, 269-274.

40. Feng, S.X.; Zhang, L.; Hao, R.; Zhou, T.Q.; LI, X.H. Determination of physcion in plasma by SPE-HPLC and its pharmacokinetic study in rats. J. Jinan Univ. (Nat. Sci. Med. Ed.) 2017, 38, 109-113.

41. Wang, C.; Zhou, Y.; Gong, X.; Zheng, L.; Li, Y. In vitro and in situ study on characterization and mechanism of the intestinal absorption of 2,3,5,4'-tetrahydroxy-stilbene-2-O- $\beta$-D-glucoside. BMC Pharmacol. Toxicol. 2020, 21, 7-13. [CrossRef]

42. Liu, W.; Feng, Q.; Li, Y.; Ye, L.; Hu, M.; Liu, Z. Coupling of UDP-glucuronosyltransferases and multidrug resistance-associated proteins is responsible for the intestinal disposition and poor bioavailability of emodin. Toxicol. Appl. Pharmacol. 2012, 265, 316-324. [CrossRef]

43. Teng, Z.; Yuan, C.; Zhang, F.; Huan, M.; Cao, W.; Li, K.; Yang, J.; Cao, D.; Zhou, S.; Mei, Q. Intestinal Absorption and First-Pass Metabolism of Polyphenol Compounds in Rat and Their Transport Dynamics in Caco-2 Cells. PLoS ONE 2012, 7, e29647. [CrossRef]

44. Zhang, Y.; Wang, P.; Wang, J.R.; Yu, Y.; Meng, X. Study of intestinal absorption of emodin in one-way intestinal perfusion rat model. Tradit. Chin. Drug Res. Clin. Pharmacol. 2012, 23, 286-290.

45. Teng, Z.-H.; Zhou, S.-Y.; Ran, Y.-H.; Liu, X.-Y.; Yang, R.-T.; Yang, X.; Yuan, C.-J.; Mei, Q.-B. Cellular Absorption of Anthraquinones Emodin and Chrysophanol in Human Intestinal Caco-2 Cells. Biosci. Biotechnol. Biochem. 2007, 71, 1636-1643. [CrossRef]

46. Wang, P.; Meng, X.L.; Wang, J.R.; Liu, H.; Yang, Y.; Liu, R. Intestinal absorption kinetics of rhubarb mixture free anthraquinones in rats. Lishizhen Med. Mater. Med. Res. 2011, 22, 790-792.

47. Bachmann, M.; Schlatter, C. Metabolism of $\left[{ }^{14} \mathrm{C}\right]$ emodin in the rat. Xenobiotica 1981, 11, 217-225. [CrossRef] [PubMed]

48. Sun, Y.; Wang, Y.X.; Chen, Q.H. Absorption, distribution and excretion of physcion in rat. J. China Pharm. Univ. 1988, 19, 179-181.

49. Wang, C.Y.; Guo, D.; Yuan, Z.F.; Feng, X.; Zhang, L. Metabolism of stilbene glycoside in rats and in vitro. Chin. J. Pharm. 2009, 40, 120-123.

50. Liu, W.; Tang, L.; Ye, L.; Cai, Z.; Xia, B.; Zhang, J.; Hu, M.; Liu, Z. Species and Gender Differences Affect the Metabolism of Emodin via Glucuronidation. AAPS J. 2010, 12, 424-436. [CrossRef] [PubMed]

51. Shia, C.-S.; Hou, Y.-C.; Tsai, S.-Y.; Huieh, P.-H.; Leu, Y.-L.; Chao, P.-D.L. Differences in pharmacokinetics and ex vivo antioxidant activity following intravenous and oral administrations of emodin to rats**Chi-Sheng Shia and Yu-Chi Hou contributed equally to this work. J. Pharm. Sci. 2010, 99, 2185-2195. [CrossRef] [PubMed]

52. Teng, Z.-H.; Zhou, S.-Y.; Yang, R.-T.; Liu, X.-Y.; Liu, R.-W.; Yang, X.; Zhang, B.-L.; Yang, J.-Y.; Cao, D.-Y.; Mei, Q.-B. Quantitation assay for absorption and first-pass metabolism of emodin in isolated rat small intestine using liquid chromatography-tandem mass spectrometry. Biol. Pharm. Bull. 2007, 30, 1628-1633. [CrossRef]

53. Song, R.; Xu, F.; Zhang, Z.; Liu, Y.; Dong, H.; Tian, Y. Structural elucidation ofin vitrometabolites of emodin by liquid chromatography-tandem mass spectrometry. Biomed. Chromatogr. 2008, 22, 1230-1236. [CrossRef]

54. Mueller, S.O.; Stopper, H.; Dekant, W. Biotansfermatioin of the anthraquinones emodin and chrysophanole by cytochrome P450 enzymes. Drug Metab. Dispos. 1998, 26, 540-546.

55. Qin, X.; Peng, Y.; Zheng, J. In Vitro and in Vivo Studies of the Electrophilicity of Physcion and its Oxidative Metabolites. Chem. Res. Toxicol. 2018, 31, 340-349. [CrossRef] 
56. Xing, Y.; Wang, L.; Wang, C.; Zhang, Y.; Zhang, Y.; Hu, L.; Gao, X.; Han, L.; Yang, W. Pharmacokinetic studies unveiled the drug-drug interaction between trans-2,3,5,4'-tetrahydroxystilbene-2-O-beta-d-glucopyranoside and emodin that may contribute to the idiosyncratic hepatotoxicity of Polygoni Multiflori Radix. J. Pharm. Biomed. Anal. 2019, 164, 672-680. [CrossRef]

57. Yu, Q.; Jiang, L.-L.; Luo, N.; Fan, Y.-X.; Ma, J.; Li, P.; Li, H.-J. Enhanced absorption and inhibited metabolism of emodin by 2,3,5,4'-tetrahydroxystilbene-2-O- $\beta$-D-glucopyranoside: Possible mechanisms for Polygoni Multiflori Radix-induced liver injury. Chin. J. Nat. Med. 2017, 15, 451-457. [CrossRef] [PubMed]

58. Li, R.-R.; Liu, X.; Feng, S.; Shu, S.-N.; Wang, P.-Y.; Zhang, N.; Li, J.-S.; Qu, L. Pharmacodynamics of Five Anthraquinones (Aloe-emodin, Emodin, Rhein, Chysophanol, and Physcion) and Reciprocal Pharmacokinetic Interaction in Rats with Cerebral Ischemia. Molecules 2019, 24, 1898. [CrossRef] [PubMed]

59. Lei, X.; Chen, J.; Ren, J.; Li, Y.; Zhai, J.; Mu, W.; Zhang, L.; Zheng, W.; Tian, G.; Shang, H. Liver Damage Associated with Polygonum multiflorum Thunb.: A Systematic Review of Case Reports and Case Series. Evid. Based Complement. Altern. Med. 2015, 2015, 1-9. [CrossRef] [PubMed]

60. Zhu, Y.; Liu, S.; Wang, J.; Song, H.; Li, Y.; He, T.; Ma, X.; Wang, Z.X.; Wang, L.; Zhou, K.; et al. Clinical analysis of drug-induced liver injury caused by Polygonum multiflorum and its preparations. Chin. J. Integr. Tradit. West. Med. 2015, 35, 1442-1447.

61. Liu, Y.; Wang, W.; Sun, M.; Ma, B.; Pang, L.; Du, Y.; Dong, X.; Yin, X.; Ni, J. Polygonum multiflorum-Induced Liver Injury: Clinical Characteristics, Risk Factors, Material Basis, Action Mechanism and Current Challenges. Front. Pharmacol. 2019, 10, 1467. [CrossRef] [PubMed]

62. Danan, G.; Teschke, R. RUCAM in Drug and Herb Induced Liver Injury: The Update. Int. J. Mol. Sci. 2015, 17, 14. [CrossRef]

63. Li, D.-K.; Chen, J.; Ge, Z.-Z.; Sun, Z.-X. Hepatotoxicity in Rats Induced by Aqueous Extract of Polygoni Multiflori Radix, Root of Polygonum multiflorum Related to the Activity Inhibition of CYP1A2 or CYP2E1. Evid. Based Complement. Altern. Med. 2017, 2017, 1-11. [CrossRef]

64. Shimada, T.; Yamazaki, H.; Mimura, M.; Inui, Y.; Guengerich, F.P. Interindividual variations in human liver cytochrome P-450 enzymes involved in the oxidation of drugs, carcinogens and toxic chemicals: Studies with liver microsomes of 30 Japanese and 30 Caucasians. J. Pharmacol. Exp. Ther. 1994, 270, 414-423.

65. Ma, K.; Zhang, X.; Jia, H. CYP1A2 polymorphism in Chinese patients with acute liver injury induced by Polygonum multiflorum. Genet. Mol. Res. 2014, 13, 5637-5643. [CrossRef]

66. Li, C.; Rao, T.; Chen, X.; Zou, Z.; Wei, A.; Tang, J.; Xiong, P.; Li, P.; Jing, J.; He, T.; et al. HLA-B*35:01Allele Is a Potential Biomarker for PredictingPolygonum multiflorum-Induced Liver Injury in Humans. Hepatology 2019, 70, 346-357. [CrossRef]

67. Malhi, H.; Gores, G.J. Cellular and Molecular Mechanisms of Liver Injury. Gastroenterology 2008, 134, 1641-1654. [CrossRef] [PubMed]

68. Wang, K. Molecular mechanisms of hepatic apoptosis. Cell Death Dis. 2014, 5, e996. [CrossRef] [PubMed]

69. Yang, X.; Zhang, Y.; Liu, Y.; Chen, C.; Xu, W.; Xiao, H. Emodin induces liver injury by inhibiting the key enzymes of FADH/NADPH transport in rat liver. Toxicol. Res. 2018, 7, 888-896. [CrossRef] [PubMed]

70. Lin, L.; Liu, Y.; Fu, S.; Qu, C.; Li, H.; Ni, J. Inhibition of Mitochondrial Complex Function-The Hepatotoxicity Mechanism of Emodin Based on Quantitative Proteomic Analyses. Cells 2019, 8, 263. [CrossRef]

71. Dong, X.; Ni, B.; Fu, J.; Yin, X.; You, L.; Leng, X.; Liang, X.; Ni, J. Emodin induces apoptosis in human hepatocellular carcinoma HepaRG cells via the mitochondrial caspase-dependent pathway. Oncol. Rep. 2018, 40, 1985-1993. [CrossRef]

72. Schadt, H.S.; Wolf, A.; Pognan, F.; Chibout, S.-D.; Merz, M.; Kullak-Ublick, G.A. Bile acids in drug induced liver injury: Key players and surrogate markers. Clin. Res. Hepatol. Gastroenterol. 2016, 40, 257-266. [CrossRef]

73. Jiang, L.-L.; Zhao, N.-S.; Fan, Y.-X.; Yu, Q.; Lai, Y.-S.; Li, P.; Li, H.-J. Transcriptome analysis to assess the cholestatic hepatotoxicity induced by Polygoni Multiflori Radix: Up-regulation of key enzymes of cholesterol and bile acid biosynthesis. J. Proteom. 2018, 177, 40-47. [CrossRef]

74. Wang, T.; Wang, J.-Y.; Zhou, Z.-X.; Jiang, Z.-Z.; Li, Y.-Y.; Zhang, L.; Zhang, L.-Y. Study on hepatotoxicity of aqueous extracts of Polygonum multiflorum in rats after 28-day oral administration: Cholestasis-related mechanism. China J. Chin. Mater. Medica 2015, 40, 2163-2167. 
75. Zhao, D.S.; Jiang, L.; Fan, Y.; Dong, L.; Ma, J.; Dong, X.; Xu, X.; Li, P.; Li, H. Identification of urine tauro-beta-muricholic acid as a promising biomarker in Polygoni Multiflori Radix-induced hepatotoxicity by targeted metabolomics of bile acids. Food Chem. Toxicol. 2017, 108, 532-542. [CrossRef]

76. Dong, Q.; Li, N.; Li, Q.; Zhang, C.-E.; Feng, W.-W.; Li, G.-Q.; Li, R.-Y.; Tu, C.; Han, X.; Bai, Z.-F.; et al. Screening for biomarkers of liver injury induced by Polygonum multiflorum: A targeted metabolomic study. Front. Pharmacol. 2015, 6, 217. [CrossRef]

77. Wei, J.; Chen, J.; Fu, L.; Han, L.; Gao, X.; Sarhene, M.; Hu, L.; Zhang, Y.; Fan, G. Polygonum multiflorum Thunb suppress bile acid synthesis by activating Fxr-Fgf15 signaling in the intestine. J. Ethnopharmacol. 2019, 235, 472-480. [CrossRef] [PubMed]

78. Kang, L.; Si, L.; Rao, J.; Li, D.; Wu, Y.; Wu, S.; Wu, M.; He, S.; Zhu, W.; Wu, Y.; et al. Polygoni Multiflori Radix derived anthraquinones alter bile acid disposition in sandwich-cultured rat hepatocytes. Toxicol. In Vitro 2017, 40, 313-323. [CrossRef] [PubMed]

79. Etu, C.; Egao, D.; Eli, X.-F.; Eli, C.-Y.; Eli, R.-S.; Ezhao, Y.-L.; Eli, N.; Ejia, G.-L.-C.; Epang, J.-Y.; Ecui, H.-R.; et al. Inflammatory stress potentiates emodin-induced liver injury in rats. Front. Pharmacol. 2015, 6, 233. [CrossRef]

80. Zhang, Y.-H.; Yang, X.-W.; Dai, Y.-H.; Xiao, H.-B. Effects of emodin on lipid accumulation and inflammation in hepatocytes. China J. Chin. Mater. Med. 2019, 44, 2820-2826.

81. Li, H.; Wang, X.; Liu, Y.; Pan, D.; Wang, Y.; Yang, N.; Xiang, L.; Cai, X.; Feng, Y. Hepatoprotection and hepatotoxicity of Heshouwu, a Chinese medicinal herb: Context of the paradoxical effect. Food Chem. Toxicol. 2017, 108, 407-418. [CrossRef]

82. Dang, S.; Zhang, X.; Jia, X.-L.; Cheng, Y.-A.; Song, P.; Liu, E.-Q.; He, Q.; Li, Z.-F. Protective effects of emodin and astragalus polysaccharides on chronic hepatic injury in rats. Chin. Med. J. 2008, 121, 1010-1014. [CrossRef]

83. Wu, L.; Chen, Y.; Liu, H.; Zhan, Z.; Liang, Z.; Zhang, T.; Cai, Z.; Ye, L.; Liu, M.; Zhao, J.; et al. Emodin-induced hepatotoxicity was exacerbated by probenecid through inhibiting UGTs and MRP2. Toxicol. Appl. Pharmacol. 2018, 359, 91-101. [CrossRef]

84. Di, X.; Wang, X.; Liu, Y. Effect of piperine on the bioavailability and pharmacokinetics of emodin in rats. J. Pharm. Biomed. Anal. 2015, 115, 144-149. [CrossRef]

85. Gao, D.; Pang, J.-Y.; Zhang, C.-E.; Li, C.-Y.; Tu, C.; Zhang, H.-Z.; Niu, M.; Xiong, Y.; Xiao, X.-H.; Zhao, K.-J.; et al. Poria Attenuates Idiosyncratic Liver Injury Induced by Polygoni Multiflori Radix Praeparata. Front. Pharmacol. 2016, 7. [CrossRef]

86. Andersen, M.E. Toxicokinetic modeling and its applications in chemical risk assessment. Toxicol. Lett. 2003, 138, 9-27. [CrossRef]

Publisher's Note: MDPI stays neutral with regard to jurisdictional claims in published maps and institutional affiliations.

(C) 2020 by the authors. Licensee MDPI, Basel, Switzerland. This article is an open access article distributed under the terms and conditions of the Creative Commons Attribution (CC BY) license (http://creativecommons.org/licenses/by/4.0/). 